\title{
MFSD2A is a novel lung tumour suppressor gene whose expression is modulated by a $5^{\prime}$-region polymorphism
}

\author{
Francesca Colombo ${ }^{1 *}$, Monica Spinola ${ }^{1,2}$, Felicia S Falvella', James P Sullivan², David S Shames ${ }^{2}$, Luc Girard ${ }^{2}$, \\ Paola Spessotto ${ }^{3}$, John D Minna ${ }^{2}$, Tommaso A Dragani ${ }^{1}$ \\ From 16th International Charles Heidelberger Symposium on Cancer Research \\ Coimbra, Portugal. 26-28 September 2010
}

MFSD2A gene maps on chromosome 1p34, within a linkage disequilibrium block containing genetic elements associated with progression of lung cancer, even if with some discrepancies in Asian and Caucasian populations attributable to ethnic differences in allelic frequencies of the functional genetic variations mapping in this locus. Here we show that MFSD2A expression is strongly downregulated in non-small cell lung cancer cell lines of different histotypes and in primary lung adenocarcinomas. Investigating, by luciferase reporter assay, three single nucleotide polymorphisms (SNPs), mapping in MFSD2A 5'-regulatory region, for their putative effects on gene transcription, we find that rs12072037 SNP (polymorphic in Asians, but not in Caucasian) is able to modulate transcriptional activity of MFSD2A promoter in cell lines expressing transcription factors potentially binding to the SNP site. Microarray analysis showed that MFSD2A upregulation modulates transcript levels of genes involved in cell cycle control and interaction with the extracellular matrix. Exogenous expression of MFSD2A induced a significant reduction of tumour colony number in vitro and tumour volume in vivo. In addition, lung tumour cells transfected with MFSD2A were blocked at the G1 phase of cell cycle progression and showed impaired adhesion and migration in vitro. Together, these data suggest that MFSD2A is a novel tumour suppressor gene that regulates cell cycle progression and matrix attachment. The functional variation in MFSD2A 5'-region influencing promoter activity may be involved in modulation of MFSD2A transcript

* Correspondence: francesca.colombo@istitutotumori.mi.it

${ }^{1}$ Fondazione IRCCS Istituto Nazionale Tumori, Milan, Italy

Full list of author information is available at the end of the article levels in normal and lung tumours, and be associated with lung cancer progression.

\section{Author details}

${ }^{1}$ Fondazione IRCCS Istituto Nazionale Tumori, Milan, Italy. ${ }^{2}$ University of Texas Southwestern Medical Center, Dallas, TX, USA. ${ }^{3}$ Centro di Riferimento

Oncologico di Aviano, Aviano, Italy.

Published: 24 September 2010

\section{doi:}

Cite this article as: Colombo et al:: MFSD2A is a novel lung tumour suppressor gene whose expression is modulated by a $5^{\prime}$-region polymorphism. BMC Proceedings 2010 4(Suppl 2):P55.
Submit your next manuscript to BioMed Central and take full advantage of:

- Convenient online submission

- Thorough peer review

- No space constraints or color figure charges

- Immediate publication on acceptance

- Inclusion in PubMed, CAS, Scopus and Google Scholar

- Research which is freely available for redistribution

Submit your manuscript at www.biomedcentral.com/submit
Biomed Central 